\title{
Maternal and perinatal outcome of eclampsia in a tertiary care centre
}

\author{
Sasmita Swain, Sujata Singh, Lucy Das, Balaram Sahoo*
}

Department of Obstetrics \& Gynaecology, SCB Medical College, Cuttack, Odisha, India

Received: 29 November 2015

Accepted: 07 January 2016

\section{*Correspondence:}

Dr. Balaram Sahoo,

E-mail: drbalaramsahoo1977@gmail.com

Copyright: (c) the author(s), publisher and licensee Medip Academy. This is an open-access article distributed under the terms of the Creative Commons Attribution Non-Commercial License, which permits unrestricted non-commercial use, distribution, and reproduction in any medium, provided the original work is properly cited.

\begin{abstract}
Background: Eclampsia is associated with devastating maternal and fetal complications. The main objective was to study the perinatal and maternal outcome and the causative factors for the mortality and morbidity in eclampsia patients admitted to this hospital and to explore the factors contributing to the alarming situation.

Methods: 218 eclampsia cases admitted to the labour room in Department of Obstetrics \& Gynaecology, SCB Medical College Cuttack, Odisha, India from Jan 2013 to Sept 2014 enrolled for the study.

Results: In this study 218 eclampsia cases were studied. The incidence of eclampsia in S.C.B.MCH during study period was $1.39 \%$. Most of the patients were primigravida accounting $83.48 \%$ out of which $74.31 \%$ were antepartum, $14.22 \%$ were intrapartum and $11.47 \%$ were postpartum. $44.04 \%$ of cases had no ANC and 40.36 irregular ANC. Occurrence of onset of eclampsia at $<34$ weeks GA $27.53 \%, 35-37$ weeks $43.12 \%$ and $>38$ weeks $29.35 \%$. Most of patients were from rural area $(97.50 \%)$ and having low socioeconomic status $(83.94 \%)$ and illiterate. Out of 218 cases $46.33 \%$ patients had vaginal delivery, $3.21 \%$ patients had vaginal delivery with instrumentation.

Conclusions: There is a need of proper antenatal care to prevent eclampsia and the need for intensive monitoring of women with eclampsia throughout hospitalization to improve both the maternal and perinatal outcome.
\end{abstract}

Keywords: Eclampsia, Perinatal outcome, Maternal transfer, Magnesium sulphate

\section{INTRODUCTION}

Eclampsia is a serious obstetric complication peculiar to pregnancy and may appear before, during or after labour. It is characterized by hypertension, proteinuria, edema and tonic clonic seizure with or without loss of consciousness. It still remains the second most common cause of maternal and perinatal morbidity and mortality in under privileged population. Globally eclampsia is the fourth most common cause of maternal death, accounting for $12 \%$ of maternal mortalities. ${ }^{1}$ There is a wide range of variation in maternal and perinatal mortalities in different countries. It is one of the major causes of maternal deaths in India. In the annual report 2001-2002, Ministry of Health and Family welfare, Delhi, declares that hypertensive disorders of pregnancy accounts for $8 \%$ of all maternal death. Perinatal mortality varies from $30 \%-60 \% .^{1}$ Adequate antenatal care with improved medical and obstetric facility and effective management has decreased the incidence of eclampsia to a great extent in developed countries.

Eclampsia is defined as the development of convulsions and/or unexplained coma during pregnancy or postpartum in patients with signs and symptoms of preeclampsia. Eclampsia is associated with serious maternal and perinatal complications. The incidence of eclampsia in developed countries range from 1 in 2000 to 1 in 3448 pregnancies which is much lower than in developing countries like India. The incidence of eclampsia in India has been quoted as $1.56 \% .^{2}$ Majority of cases of eclampsia are young primigravidas and those with no prior antenatal care. Though not all cases of eclampsia can be prevented, majority of cases can be prevented by early detection and effective treatment of preeclampsia, for which good ANC services are needed. ${ }^{3}$ 
Eclamptic convulsions leading to maternal and perinatal morbidity and mortality could be prevented by appropriate antenatal care. The reduction in both maternal and perinatal mortality remains the yard stick of success in the management of eclampsia. Better health care facilities, improvement of socio-economic and educational status of the people and recognition of the seriousness of problem and availing the health care facility by the people themselves, adequate antenatal supervision followed by early treatment and timely interventions will greatly reduce the morbidity and mortality.

\section{METHODS}

This study was done on "Maternal and Perinatal outcome of eclampsia in a tertiary care centre" (SCB MCH) from January 2013 to September 2014. The study was conducted in Obstetrics and Gynecology Department, SCB Medical College Cuttack, Odisha, India. The present study aims to determine the factors affecting the maternal and perinatal outcome of eclamptic mothers. Women with other causes of convulsions were excluded.

It was an observational study. Patients with eclampsia were admitted through emergency. Inclusion criteria was the patients developing eclampsia in second half of pregnancy or within ten days after delivery; and exclusion criteria was patients with convulsion due to epilepsy, cerebral cause, malaria or any other metabolic cause and patients presenting ten days or more after delivery.

A detailed history was taken from attendants or from patient (if conscious and well oriented in time and space), regarding gestational age, or time passed after delivery, number of convulsion and their nature, history of raised blood pressure, proteinuria, swelling of feet, headache, epigastric pain, visual disturbances, vomiting, urinary problem or bleeding per vaginum. A thorough general physical and systemic examination was performed, recording blood pressure, pulse, temperature, edema, jaundice and pallor. Lungs and heart were auscultated to note any abnormalities. Reflexes were checked. Obstetrical examination included abdominal examination to determine lie and presentation of fetus, amount of liquor, any element of intrauterine growth retardation and fetal heart rate (if alive). Vaginal examination performed to note degree of cervical dilatation, effacement, station of presenting part and pelvic capacity. Mode of delivery (vaginal / abdominal route) was decided according to the bishop score, patient's condition and fetal condition. After delivery patients were observed in intensive care unit for 24-48 hours and patients were followed up for complication for up to ten days. All of these information's were recorded on a Performa. Lab investigations included: Blood group and $\mathrm{Rh}$ factor, complete blood examination, platelet count, serum electrolytes, serum urea, serum creatinine, serum uric acid, liver function tests, complete urine analysis, 24 hours urinary protein estimation and Ultrasonography.
Ethical clearance has been taken from Institutional Ethical committee. Informed consent was taken from every patients who had taken part in the study.

\section{RESULTS}

During the study period there were 218 women with eclampsia among 15677 deliveries ( 1 in 72 deliveries).The incidence of eclampsia in SCB Medical College during the study period was $1.39 \%$. All these patients were treated with magnesium sulphate by Prichard regime. 98\% were unbooked, $6(2.75 \%)$ gave previous history of PIH and 2 $(0.92 \%)$ gave history of eclampsia. It is important to note that the classic triad used to diagnose pre-eclampsia was not present in all women with eclampsia. $3.21 \%$ cases were between $15-19$ years of age , $63.30 \%$ cases were between 20-24 years of age , $26.61 \%$ were between 25-29 years of age, $6.42 \%$ were between $30-34$ years of age and $0.46 \%$ cases were of 35 years and above. $83.48 \%$ cases were primigravida, $11.92 \%$ were second gravidae, $1.37 \%$ were third gravidae and $3.23 \%$ of cases were fourth gravidae and above.

$74.31 \%$ cases were antepartum, $14.22 \%$ were intrapartum and $11.43 \%$ were postpartum. $5.50 \%$ of cases were between $20-28$ weeks of gestation age, $22.03 \%$ of cases were between 29-34 weeks of gestation, $43.12 \%$ were between 35-37 weeks, $25.23 \%$ were between 38-40 weeks and $4.12 \%$ were $>40$ weeks of gestation. $15.60 \%$ of cases had regular ANC, $40.36 \%$ had irregular ANC and $44.04 \%$ had no ANC. $97.25 \%$ of cases were from rural area and $2.75 \%$ were from urban area. $37.61 \%$ of cases were illiterate, $27.08 \%$ had primary education, $31.19 \%$ had high school education, $1.83 \%$ had plus two education and $2.29 \%$ were graduate. $83.94 \%$ of cases were from lower socioeconomic status, $15.14 \%$ of cases were from middle socioeconomic status and $0.92 \%$ of cases from upper socioeconomic status. $62.39 \%$ of the cases were referred from specialist, $30.28 \%$ referred from FRU and $7.33 \%$ were not referred. $44.04 \%$ cases were conscious during admission, $49.08 \%$ were conscious but disoriented and 6.88 were unconscious.

Table 1 shows $47.25 \%$ had systolic blood pressure $>160$ $\mathrm{mmHg}, 31.19 \%$ had between 140 and $160 \mathrm{mmHg}, 20.18 \%$ had $<140 \mathrm{mmHg}$ and $1.38 \%$ SBP not recordable. There were a higher numbers of maternal deaths when SBP was more than $160 \mathrm{mmHg}$.

Table 2 shows $35.32 \%$ of had diastolic blood pressure $>110 \mathrm{mmHg}, 44.03 \%$ had between $90-110 \mathrm{mmHg}, 19.27 \%$ had $<90 \mathrm{mmHg}$ and $1.38 \%$ DBP not recordable. There were a high number of maternal deaths when DBP was more than equal to $110 \mathrm{mmHg}$.

Table 3 shows there was higher maternal death associated with more protenuria. 
Table 4 shows that in primigravida the case fatality rate was $3.84 \%$ and for multigravida the case fatality rate was $16.67 \%$. Overall maternal mortality was $5.96 \%$.

Table 1: Systolic blood pressure at the time of admission.

\begin{tabular}{|llll|}
\hline $\begin{array}{l}\text { Blood pressure } \\
(\text { mmhg) }\end{array}$ & $\begin{array}{l}\text { No. of } \\
\text { cases }\end{array}$ & $\begin{array}{l}\text { Percentage } \\
(\%)\end{array}$ & $\begin{array}{l}\text { Maternal } \\
\text { death }\end{array}$ \\
\hline$>160$ & 103 & 47.25 & 6 \\
\hline $140-160$ & 68 & 31.19 & 1 \\
\hline$<140$ & 44 & 20.18 & 3 \\
\hline Not recordable & 03 & 1.38 & 3 \\
\hline Total & 218 & 100 & 13 \\
\hline
\end{tabular}

Table 2: Diastolic blood pressure at the time of admission.

\begin{tabular}{|llll|}
\hline $\begin{array}{l}\text { Blood pressure } \\
(\mathbf{m m} \text { hg) }\end{array}$ & $\begin{array}{l}\text { No. of } \\
\text { cases }\end{array}$ & $\begin{array}{l}\text { Percentage } \\
(\%)\end{array}$ & $\begin{array}{l}\text { Maternal } \\
\text { death }\end{array}$ \\
\hline$>110$ & 77 & 35.32 & 4 \\
\hline $90-110$ & 96 & 44.03 & 5 \\
\hline$<90$ & 42 & 19.27 & 1 \\
\hline Not recordable & 03 & 1.38 & 3 \\
\hline Total & 218 & 100 & 13 \\
\hline
\end{tabular}

Table 3: Degree of proteinuria at the time of admission.

\begin{tabular}{|llll|}
\hline Urine albumin & $\begin{array}{l}\text { No. of } \\
\text { cases }\end{array}$ & $\begin{array}{l}\text { Percentage } \\
(\%)\end{array}$ & $\begin{array}{l}\text { Maternal } \\
\text { death }\end{array}$ \\
\hline $4+$ & 63 & 28.90 & 6 \\
\hline $3+$ & 71 & 32.57 & 5 \\
\hline $2+$ & 57 & 26.15 & 2 \\
\hline $1+$ & 19 & 8.72 & 0 \\
\hline Negative & 08 & 3.66 & 0 \\
\hline Total & 218 & 100 & 13 \\
\hline
\end{tabular}

Table 4: Maternal mortality in relation to parity.

\begin{tabular}{|llll|}
\hline Parity & No. of cases & No.of deaths & $\begin{array}{l}\text { CFR } \\
(\%)\end{array}$ \\
\hline Primigravida & 182 & 7 & 3.84 \\
\hline Multigravida & 36 & 6 & 16.67 \\
\hline Total & 218 & 13 & 5.96 \\
\hline
\end{tabular}

\section{Maternal outcome}

There were 13 maternal deaths out of 218 eclampsias. six died undelivered, $46.33 \%$ of cases delivered vaginaly, $3.21 \%$ delivered vaginaly with instrumentation and $47.70 \%$ delivered by Caesarean section. For primigravida the case fatality rate was $3.84 \%$ and for multigravida the case fatality rate was $16.67 \%$.

Table 5 shows in antepartum eclampsia the case fatality was $6.79 \%$, for intrapartum eclampsia it was $3.22 \%$ and for postpartum eclampsia it was $4 \%$. The overall case fatality for eclampsia was $5.96 \%$.
Table 6 shows that $61.54 \%$ of the deaths had $>4$ convulsions and $38.46 \%$ had $1-3$ convulsions.

Table 5: Maternal mortality in relation to type of eclampsia.

\begin{tabular}{|llll|}
\hline $\begin{array}{l}\text { Type of } \\
\text { eclampsia }\end{array}$ & No. of cases & No.of deaths & $\begin{array}{l}\text { CFR } \\
(\%)\end{array}$ \\
\hline Antepartum & 162 & 11 & 6.79 \\
\hline Intrapartum & 31 & 1 & 3.22 \\
\hline Postpartum & 25 & 1 & 4.0 \\
\hline Total & 218 & 13 & 5.96 \\
\hline
\end{tabular}

Table 6: Maternal mortality in relation to no. of convulsion.

\begin{tabular}{|lll|}
\hline $\begin{array}{l}\text { No.of } \\
\text { convulsion }\end{array}$ & No. of deaths & $\begin{array}{l}\text { Percentage of } \\
\text { deaths }\end{array}$ \\
\hline $1-3$ & 5 & 38.46 \\
\hline$>4$ & 8 & 61.54 \\
\hline Total & 13 & 100 \\
\hline
\end{tabular}

Table 7: Causes of maternal mortality in eclampsia.

\begin{tabular}{|lll|}
\hline Cause of death & $\begin{array}{l}\text { No. of } \\
\text { cases }\end{array}$ & $\begin{array}{l}\text { Percentage } \\
(\%)\end{array}$ \\
\hline Cerebral hemorrhage & 1 & 7.69 \\
\hline Pulmonary edema & 6 & 46.17 \\
\hline Acute renal failure & 1 & 7.69 \\
\hline PPH with shock & 2 & 15.38 \\
\hline DIC & 2 & 15.38 \\
\hline Cardiac failure & 1 & 7.69 \\
\hline Total & 13 & 100 \\
\hline
\end{tabular}

Table 8: Maternal morbidity due to eclampsia.

\begin{tabular}{|lll|}
\hline Morbidities & $\begin{array}{l}\text { No. of } \\
\text { cases }\end{array}$ & $\begin{array}{l}\text { Percentage } \\
(\%)\end{array}$ \\
\hline Cerebral hemorrhage & 6 & 2.75 \\
\hline Pulmonary edema & 18 & 8.25 \\
\hline Acute Renal failure & 30 & 13.76 \\
\hline Shock & 12 & 5.50 \\
\hline Hellp syndrome & 10 & 4.59 \\
\hline Jaundice & 17 & 7.80 \\
\hline Cardiac failure & 2 & 0.91 \\
\hline Septicemia & 18 & 8.25 \\
\hline Pyrexia & 34 & 15.60 \\
\hline PPH & 28 & 12.84 \\
\hline DIC & 14 & 6.42 \\
\hline $\begin{array}{l}\text { ARDS / aspration } \\
\text { pneumonia }\end{array}$ & 2 & 0.91 \\
\hline Abruptio placentae & 15 & 6.88 \\
\hline Acute hepatic failure & 4 & 1.83 \\
\hline $\begin{array}{l}\text { Retinal oedema, } \\
\text { blindness }\end{array}$ & 8 & 3.67 \\
\hline
\end{tabular}


Table 7 shows different causes of maternal mortality in eclampsia.

Table 8 shows different maternal morbidity due to eclampsia.

Table 9 shows that $69.23 \%$ of maternal death occurred before 12 hours, $7.69 \%$ between $13-24 \%, 15.38 \%$ between 25-48 hours and $7.69 \%$ more than 48 hours of admission.

Table 10 shows that LSCS deliveries had maternal death rate $0.96 \%$ and perineal mortality rate $16.35 \%$. Vaginal deliveries had maternal death rate $5.56 \%$ and perinatal mortality rate $42.59 \%$.

Table 9: Admission death interval.

\begin{tabular}{|lll|}
\hline Duration (hours) & No.of deaths & Percentage $(\%)$ \\
\hline$<12$ & 9 & 69.23 \\
\hline $13-24$ & 1 & 7.69 \\
\hline $25-48$ & 2 & 15.38 \\
\hline$>48$ & 1 & 7.69 \\
\hline Total & 13 & 100 \\
\hline
\end{tabular}

Table 10: Fetal and perinatal outcome depending upon the mode of delivery.

\begin{tabular}{|c|c|c|c|c|c|}
\hline \multirow{2}{*}{$\begin{array}{l}\text { Mode of } \\
\text { delivery }\end{array}$} & \multirow{2}{*}{$\begin{array}{l}\text { No.of } \\
\text { cases }\end{array}$} & \multicolumn{2}{|c|}{$\begin{array}{l}\text { Maternal } \\
\text { death }\end{array}$} & \multicolumn{2}{|c|}{$\begin{array}{l}\text { Perinatal } \\
\text { deaths }\end{array}$} \\
\hline & & $\begin{array}{l}\text { No. of } \\
\text { cases }\end{array}$ & $(\%)$ & $\begin{array}{l}\text { No. of } \\
\text { cases }\end{array}$ & $(\%)$ \\
\hline LSCS & 104 & 01 & 0.96 & 17 & 16.35 \\
\hline VD & 108 & 06 & 5.56 & 46 & 42.59 \\
\hline Undelivered & 06 & 06 & & - & - \\
\hline Total & 218 & 13 & & 63 & \\
\hline
\end{tabular}

\section{Perinatal outcome}

The 218 pregnancies resulted in 213 births ( 5 sets of twins, and 6 women died undelivered). There were 46 still births and 63 perinatal deaths for a total perinatal mortality of $31.50 \%$ which was largely due to birth asphyxia 11 . It is important to emphasize that in 63 of the 207 cases of perinatal deaths the infants had birth weight of $<1.5 \mathrm{~kg}$. In addition 6 of the still births were due to congenital anomalies.

Table 11 shows that out of 218 cases, 206 cases were $>28$ weeks of gestation. Out of 206 cases $75.73 \%$ were live births, $21.35 \%$ were still birth and $2.92 \%$ of cases mother died before delivery.

Table 12 shows out of 218 cases 206 cases were $>28$ weeks of gestation. Out of 206 cases $74.75 \%$ were live births, $22.33 \%$ were still births and $2.92 \%$ (6 cases) mother died before delivery.
Perinatal mortality rate $=$ still births + early neonatal deaths/Total no. of deliveries $=46+17 / 200=31.50 \%$

It shows total perinatal mortality rate is $31.50 \%$. Still births accounts for $73.01 \%$ and early neonatal death accounts for $26.98 \%$ of total perinatal mortality.

Table 13 shows $38.83 \%$ of perinatal deaths occurred when maternal blood systolic pressure $>160 \mathrm{mmHg}, 41.55 \%$ when diastolic blood pressure $>110 \mathrm{mmHg}, 18.75 \%$ when blood systolic pressure $<160 \mathrm{mmHg}, 21.73 \%$ when diastolic blood pressure $<110 \mathrm{mmHg}$.

Table 14 shows the relationship between urine albumin and perinatal outcome. Urine albumin more than $2^{+}$had more perinatal deaths.

Table 15 shows $47.94 \%$ of perinatal deaths occurred when uric acid level more than 7.1, 27.27\% deaths occurred when uric acid level between 5.6 to 7 and $9.30 \%$ perinatal deaths occurred when uric acid level less than 5.5.

Table 16 shows $9.20 \%$ babies had Apgar score between 04, 24.14\% had Apgar score between 5-7 and 66.66\% had Apgar score between 8-10.

Table 17 shows $27.27 \%$ of newborn were less than $1.5 \mathrm{~kg}$, $50.45 \%$ were between $1.6-2.5 \mathrm{~kg}, 18.18 \%$ were between $2.6-3 \mathrm{~kg}$ and $4.10 \%$ were more than $3 \mathrm{kgs}$.

Table 18 shows out of total live births $48.47 \%$ were preterm, $22.43 \%$ had IUGR, $17.95 \%$ had developed birth asphyxia, $3.20 \%$ developed HIE, $1.28 \%$ each developed IVH and septicaemia, $3.85 \%$ had developed jaundice and $1.92 \%$ had developed seizure.

Table 19 shows $36.84 \%$ of neonatal mortality due to prematurity, $57.89 \%$ due to birth asphyxia and $5.26 \%$ due to IUGR.

Table 11: Perinatal outcome in eclampsia.

\begin{tabular}{|lll|}
\hline Outcome & No. of cases & Percentage (\%) \\
\hline Live birth & 161 & 75.59 \\
\hline Still birth & 46 & 21.60 \\
\hline Not delivered & 6 & 2.81 \\
\hline Total & 213 & 100 \\
\hline
\end{tabular}

Table 12: Perinatal deaths in eclamptic patients.

\begin{tabular}{|lll|}
\hline Outcome & No of cases & $\begin{array}{l}\text { Percentage } \\
(\%)\end{array}$ \\
\hline Still birth & 46 & 73.01 \\
\hline Early neonatal death & 17 & 26.98 \\
\hline Perinatal death & 63 & 100 \\
\hline
\end{tabular}


Table 13: Blood pressure and perinatal outcome in eclampsia.

\begin{tabular}{|llll|}
\hline BP & No. of cases & $\begin{array}{l}\text { Perinatal } \\
\text { death }\end{array}$ & $\begin{array}{c}\text { Percentage } \\
(\%)\end{array}$ \\
\hline$>160$ & 103 & 40 & 38.83 \\
\hline$<160$ & 112 & 21 & 18.75 \\
\hline$>110$ & 77 & 32 & 41.55 \\
\hline$<110$ & 138 & 30 & 21.73 \\
\hline
\end{tabular}

Table 14: Urine albumin and perinatal outcome.

\begin{tabular}{|llll|}
\hline $\begin{array}{l}\text { Urine } \\
\text { albumin }\end{array}$ & $\begin{array}{l}\text { No. of } \\
\text { cases }\end{array}$ & $\begin{array}{l}\text { Perinatal } \\
\text { death }\end{array}$ & $\begin{array}{l}\text { Percentage } \\
(\%)\end{array}$ \\
\hline $4+$ & 63 & 21 & 33.34 \\
\hline $3+$ & 71 & 27 & 38.03 \\
\hline $2+$ & 57 & 12 & 21.05 \\
\hline $1+$ & 19 & 2 & 10.52 \\
\hline Negative & 08 & 1 & 12.05 \\
\hline
\end{tabular}

Table 15: Uric acid level and fetomaternal outcome in eclampsia.

\begin{tabular}{|lllllr|}
\hline $\begin{array}{l}\text { Uric } \\
\text { acid } \\
\text { level in } \\
\mathrm{mEq} / \mathrm{dl}\end{array}$ & $\begin{array}{l}\text { No of } \\
\text { cases }\end{array}$ & $\begin{array}{l}\text { Maternal } \\
\text { death }\end{array}$ & $(\%)$ & $\begin{array}{l}\text { Perinatal } \\
\text { death }\end{array}$ & $(\%)$ \\
\hline$<5.5$ & 86 & 0 & - & 8 & 9.30 \\
\hline $5.6-7$ & 55 & 1 & 1.8 & 15 & 27.27 \\
\hline$>7.1$ & 73 & 7 & 9.5 & 35 & 47.94 \\
\hline
\end{tabular}

Table 16 : APGAR score at birth at 5 minutes in eclampsia.

\begin{tabular}{|lll|}
\hline APGAR score & No. of cases & Percentage (\%) \\
\hline $0-4$ & 16 & 9.94 \\
\hline $05-07$ & 42 & 26.09 \\
\hline $08-10$ & 103 & 63.97 \\
\hline Total & 161 & 100 \\
\hline
\end{tabular}

Table 17: Birth weight of the babies.

\begin{tabular}{|lll|}
\hline Birth weight $(\mathrm{kg})$ & No.of cases & Percentage $(\%)$ \\
\hline$<1.5$ & 54 & 25.35 \\
\hline $1.5-2.5$ & 110 & 51.64 \\
\hline $2.6-3$ & 40 & 18.77 \\
\hline$>3$ & 09 & 4.24 \\
\hline Total & 213 & 100 \\
\hline
\end{tabular}

Table 18: Risk factors associated with neonatal death.

\begin{tabular}{|lcc|}
\hline Cause of death & No.of death & Percentage $(\%)$ \\
\hline Preterm & 7 & 36.84 \\
\hline Birth asphyxia & 11 & 57.89 \\
\hline IUGR & 1 & 5.26 \\
\hline Total & 19 & 100 \\
\hline
\end{tabular}

Table 19: Neonatal morbidity in eclampsia (total live birth 161).

\begin{tabular}{|lll|}
\hline Morbidity & No.of neonate & Percentage $(\%)$ \\
\hline Preterm & 83 & 51.55 \\
\hline IUGR & 32 & 19.87 \\
\hline Asphyxia & 28 & 17.39 \\
\hline HIE & 5 & 3.10 \\
\hline IVH & 2 & 1.24 \\
\hline Jaundice & 6 & 3.72 \\
\hline Seizure & 3 & 1.86 \\
\hline Septicemia & 2 & 1.24 \\
\hline
\end{tabular}

\section{DISCUSSION}

The incidence of eclampsia in our study was $13.9 / 1000$ deliveries i.e. $1.39 \%$, which is less than that described by Rajashri et al (1.82\%), more than Sunitha TH $(0.7 \%))^{4,5}$ However, the incidence of eclampsia is much higher than that of developed countries like the United Kingdom (UK), where eclampsia complicates $0.05 \%$ of total deliveries. ${ }^{6}$ The incidence of eclampsia in Eastern India as quoted by Singh et al is $3.2 \%$ which is higher than ours. ${ }^{7}$ Eclampsia was more commonly seen in young pregnant women $(66.5 \%)$ and primigravidas $(83.48 \%)$ which is similar to a study done by Sunita $\mathrm{TH}$ et al $(85 \%$ and $79 \%) .{ }^{5} 95 \%$ of patients of eclampsia in our hospital were not booked with us. $44 \%$ of patients had no antenatal care and around $40 \%$ of patients had some sort of antenatal care. Lack of antenatal care is one of the important risk factors for the development of eclampsia which is proved by many studies. $93.99 \%$ of patients had no ANC as per Jain $\mathrm{S}$ et al and $76.66 \%$ had no ANC as per Swain S et al. ${ }^{3,8}$ According to studies conducted in developed countries, the percentage of eclampsia considered to be unpredictable ranged from $31 \%$ to $87 \%$ and this is because of atypical presentation of eclampsia i.e. abrupt onset, development of convulsions while receiving prophylactic $\mathrm{Mgso}_{4}$ or onset of convulsions after 48 hours of delivery or in patients without hypertension or proteinuria. But in developing countries, the preventable causes of eclampsia contribute to most cases of eclampsia because of poor ANC services. In our study $74.31 \%$ of eclampsia were antepartum, $14.22 \%$ were intrapartum and $11.47 \%$ were postpartum. In UK, $44 \%$ of eclampsia were postpartum and had lower incidence of antepartum eclampsia which could be due to good ANC surveillance. Pathogenesis of postpartum eclampsia is less understood. ${ }^{9}$ Ecalmpsia was seen in $49 \%$ of patients at term gestation in our study which is similar to a study done by Khanum $\mathrm{M}$ et al i.e. $53 \%$ at term gestation and $43 \%$ at near term gestation. ${ }^{10} 47 \%$ of patients had severe hypertension at presentation, 6 patients had normal BP recording at presentation. Mattar F et al quoted $16 \%$ of the patients had no hypertension, $20 \%-54 \%$ had severe hypertension and $30 \%-60 \%$ had mild hypertension. Hypertension is considered to be the hallmark for the diagnosis of eclampsia. The diagnosis of eclampsia is usually associated with proteinuria (at least $1+$ on dipstick). In our series $29 \%$ 
of patients had $4+, 33 \%$ had $3+, 26 \%$ had $2+, 9 \%$ had $1+$ and $3.6 \%$ had negative which is similar to the study done by Mattar F et al. ${ }^{11}$ Cesarean section was a common mode of delivery in our series (47\%) which is similar to study done by Sibai BM et al. ${ }^{12}$ Eclampsia per se is not an indication for cesarean section and mode of delivery had no significant effect on the outcome of the eclamptics as per Ibrahim A et al. ${ }^{13}$ The decision to perform cesarean section should be based on fetal gestational age, fetal condition, presence of labour, cervical Bishop score and maternal condition. Labour is usually induced with prostaglandins and early rupture of membranes and the obstetrician can monitor and await vaginal delivery once the patient is stable and convulsions are under control. Judicious and timely selection of cases for either vaginal delivery or cesarean section is going to improve the maternal and perinatal outcome. All our patients received $\mathrm{MgsO}_{4}$ as per Prichard's regimen to prevent convulsions. Only 4 patients had recurrence of convulsions while on $\mathrm{MgSO}_{4}$ regimen. Recurrence of fits increases the maternal morbidity. Efficacy of $\mathrm{MgSO}_{4}$ in prevention and treatment of eclamptic convulsions is time tested, however, protocols and dose of $\mathrm{MgSO}_{4}$ are not evidence based and narrow therapeutic index and toxicity is still a major concern in clinical use. Pritchard regimen was formulated for women of the West with high BMI but he also suggested low dose in women with small body size. ${ }^{14}$ Witlin et al also recommended dose adjustment according to patients weight or body mass index. ${ }^{15}$ Low dose regimen proved to be effective in prevention and control of convulsions in our population similar to a study done by Bangal $\mathrm{V}$ et al. ${ }^{16}$ Delay in presentation to the hospital and more number of convulsions definitely adds to maternal morbidity and mortality. There are increased rates of maternal morbidities due to eclampsia. The most common causes of maternal death are intracranial bleeding, pulmonary edema and acute renal failure secondary to abruption placentae. There were 63 perinatal deaths due to eclampsia. The most common causes of perinatal death are fetal asphyxia, prematurity, fetal growth restriction and acidosis. According to the Royal College of Obstetricians and Gynaecologists (RCOG) good antenatal services will detect and treat preeclampsia and thus reduce the incidence of eclampsia. Prompt and timely treatment of eclampsia will reduce the maternal and perinatal morbidity and mortality. ${ }^{17}$

In our study Perinatal mortality was high in patients who had a systolic Blood Pressure of $\geq 160 \mathrm{~mm}$ of $\mathrm{Hg}$, a diastolic Blood Pressure of $\geq 90-110 \mathrm{~mm}$ of $\mathrm{Hg}$, babies less than $2 \mathrm{kgs}$, urine albumin $>2+$. Perinatal mortality was low in those patients who had delivered within 6 hours of convulsion, in patients who delivered within 6 hours of commencement of treatment, babies delivered by caesarean section and in babies above $2 \mathrm{kgs}$.

Eclampsia is responsible for considerable maternal and perinatal mortality as well as maternal morbidity. Maternal morbidity includes severe bleeding from abruption placentae with its resulting coagulopathy, pulmonary edema, aspiration pneumonia, acute renal failure, cerebrovascular haemorrhage and retinal detachment. Eclampsia continues to be an important cause of maternal and perinatal morbidity and mortality. This is due to lack of proper antenatal care, low socio economic condition and lack of education. Perinatal mortality and morbidity is another concern in eclampsia patients, as the definitive treatment demands termination of pregnancy.

The basic management aims in eclampsia include attaining control of convulsions, control of blood pressure and safe delivery within a reasonable period of time. Rational use of appropriate anticonvulsants along with safe delivery should be promoted for these patients at all health service levels. Referral to a better-equipped center when necessary should be accompanied by appropriate emergency obstetric care. Health education and public awareness regarding decision to seek care on time should be promoted at all levels.

\section{CONCLUSION}

The result of this present study indicates the great need for improved health education, as most cases of eclampsia were due to ignorance and neglect. There is also a need for expansion of education and training personnel in order to recognize the high risk factors diagnose and manage preeclampsia and eclampsia as early as possible so that the severe form of the disease is prevented.

\section{Funding: No funding sources}

Conflict of interest: None declared

Ethical approval: The study was approved by the Institutional Ethics Committee

\section{REFERENCES}

1. Govt. of India (2002),Annual report 2001-2002, Ministry of Health and Family Welfare, New Delhi.

2. Andersgaard AB, Herbst A, Johansen $M$, et al. Eclampsia in Scandinavia: incidence, substandard care, and potentially preventable cases . Acta Obstet Gynecol Scand. 2006; 85(8):929-36.

3. Swain S, Ohha KN, Prakash A. Maternal and perinatal mortality due to eclampsia . Indian Pediatr. 1993;30(6):771-3.

4. Yaliwal RG, Jaju PB, Vanishree M. Eclampsia and Perinatal Outcome: A Retrospective Study in a Teaching Hospital. $\mathrm{J}$ of Clinical and Diagnostic Research.2011;5(5):1056-9.

5. Sunita TH, Desai RM. Eclampsia in a Teaching Hospital 2013 : Incidence, clinical profile and response to Magnesium Sulphate by Zuspan's regimen. IOSRJDMS. 2013;4(2):1-5.

6. Douglas KA, Redman CW. Eclampsia in the United Kingdom. BMJ. 1994;309(6966):1395-400.

7. Singh S, Behera AK. Eclampsia In Eastern India: Incidence, Demographic Profile And Response To Three Different Anticonvulsant Regimes Of Magnesium Sulphate. The Internet Journal of Gynecology and Obstetrics. 2011;15(2). 
8. Jain S, Nager S, Monga D. Maternal mortality following Eclampsia; a critical analysis of 693 cases in two teaching hospitals in Northern India. 1998;38:256-60.

9. Katz VL, Farmer R, Kuller J. Preeclampsia into eclampsia: toward a new paradigm. Am J Obstet Gynecol. 2000;182:307-12.

10. Khanum M, Ashraf F, Sahrin H. A Clinical Study of 100 Cases of Eclampsia in Rajshahi Medical College Hospital.TAJ .2004; 17(2):80-3.

11. Akhtar R, Ferdous A, Bhuiyan SN. Maternal and Fetal Outcome Of Eclamptic patients in a Tertiary Hospital ; Bangladesh Journal Of Obstetrics \& Gynaecology. 2011;26(2):77-80.

12. Manjusha S, Vandana N, Goutham R, Sneha M, Atmaram PP. Eclampsia : A retrospective study in a tertiary Care Centre: Indian Journal of pharmacy Practice. 2013;6(1):69-73.

13. Mattar F, Sibai BM. Eclampsia. VIII. Risk Factors for maternal morbidity. Am J Obstet Gynecol. 1990;163:1049-55.
14. Sibai BM. Diagnosis and management of gestational hypertension and preeclampsia. Obstet Gynecol. 2003;102:181-92.

15. Ibrahim A, Yakasai, Sule A, Gaya. Maternal and fetal outcome in patients with eclampsia at Murtala Muhammad specialist Hospital,Kano, Nigeria. Annals of African Medicine.2011;10(4):305-9.

16. Witlin AG, Sibai BM. Magnesium sulfate therapy in preeclampsia and eclampsia.Obstet Gynecol. 1998;92(5):883-9.

17. Witlin AG. Prevention and treatment of eclamptic convulsions. Clin Obstet Gynecol. 1999;42(3):507-18.

Cite this article as: Swain S, Singh S, Das L, Sahoo B. Maternal and perinatal outcome of eclampsia in a tertiary care centre. Int J Reprod Contracept Obstet Gynecol 2016;5:384-90. 